\title{
DOSSIÊ: POÉTICAS COMPUTACIONAIS
}

\section{Carlos Henrique Rezende Falci*}

As relações entre arte, tecnologia e processos de criação orientam esse dossiê sobre poéticas computacionais, em que apresentamos as várias nuances em investigação permanente pelo grupo de pesquisa em Arte Digital "1imaginári0: Poéticas computacionais". O conjunto de textos desse dossiê trafega por universos bem distintos, de modo a também enfatizar o caráter plural de tais poéticas. Uma vez que os ambientes computacionais se mostram hoje mais cada vez mais permeáveis e entrelaçados com práticas de criação diversas, parece-nos compreensível que os processos artísticos também se apropriem e se deixem infiltrar por essas poéticas. Ainda que não se possa conferir ao conjunto de textos aqui reunidos uma linha programática, entendo que essa é também a potência das investigações aqui agrupadas, pois que elas só reforçam uma instabilidade poética encontrada em lógicas computacionais. Deseja-se, com as pesquisas ora discutidas no dossiê, não só apresentar o conjunto de indagações que move os pesquisadores convidados, mas, sobretudo, instigar o leitor a se fazer perguntas e movimentar-se através dos textos, nos provocando conjuntamente para uma investigação mais autônoma, coletiva e aberta. Os cinco artigos que compõem esse dossiê são pesquisas em andamento dentro do âmbito do grupo de pesquisa 1imaginário: Poéticas computacionais, liderado pelo professor Francisco Marinho, da UFMG.

O primeiro texto desse dossiê, de autoria de Angélica Beatriz, professora da UFMG no curso de Cinema de Animação e Artes Digitais, discute a noção de progresso técnico em Vilém Flusser e Gilbert Simondon, conjugando tal análise ao modo como a arte cria modulações específicas no campo da técnica.

\footnotetext{
*Universidade Federal de Minas Gerais. Imeio: chfalci@gmail.com.

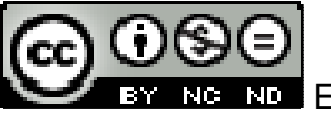

Texto Digital, Florianópolis, v. 9, n. 1, p. 169-171, jan./jul. 2013. ISSNe: 1807-9288 
Entendo que esse texto prepara bem o campo para que o leitor, a partir daí, encontre artigos voltados para experimentações ou análises em algumas áreas específicas em que técnica, sensibilidade, tecnologia e arte estejam em constante estado de tensão criativa.

Em seguida, Leonardo Souza, professor da Oi Kabum, Escola de Arte e Tecnologia, aborda os conceitos de montagem e rizoma a partir de um software criado para realização de montagens multitemporais em audiovisual. A perspectiva adotada aqui nos permite investigar de que modo o uso das tecnologias contemporâneas conjugado com processos artísticos potencializa 0 olhar individuante sobre o funcionamento dessas mesmas tecnologias. Evidencia-se no seu texto um caráter fenomenológico sobre as tecnologias contemporâneas, que também pode ser percebido na discussão do próximo artigo.

O texto de Carlos Henrique Falci, ao tratar de lugares imaginários em rede, deixa claro como a memória pode provocar novas formas de entender tanto os processos de arquivamento em ambientes programáveis, como o funcionamento mesmo dessas interfaces. Questionando a noção de arquivo como um lugar fixo que exerceria uma autoridade sobre a memória, o autor dá ênfase ao caráter obviamente instável dos processos de memória. Essa instabilidade é relacionada às interfaces programáveis, na tentativa de caracterizar o conceito de lugares imaginários, a partir do uso de metadados. $O$ texto aponta, ao seu final, a importância da construção coletiva das noções de autoridade e autonomia, na criação de memórias em ambientes programáveis.

Marília Bergamo e Francisco Marinho, também professores da UFMG, na área de Arte Digital, aprofundam a discussão em torno da autonomia, ao analisarem como modelos computacionais autorreguláveis possuem autonomia na construção de sua própria composição visual. A partir do conceito de abstração, que inicia o processo de autonomia para o elemento compositivo, o texto percorre modelos computacionais matemáticos e autorreguláveis

Texto Digital, Florianópolis, v. 9, n. 1, p. 169-171, jan./jul. 2013. ISSNe: 1807-9288 
geradores de imagens buscando associar este conceito de autonomia à própria imagem. O texto também apresenta alguns trabalhos do grupo 1maginari0: Poéticas Computacionais, que exemplificam o argumento teórico apresentado. A pesquisa provoca o pensamento sobre a relação entre agentes internos aos sistemas computacionais e o papel dos artistas que criam e manipulam tais modelos, e como as noções de produção artística podem ser repensadas a partir desse entrelaçamento.

Finalizando o dossiê, e discutindo a noção de performance sonora, Jalver Bethônico, professor na área de Design Sonoro da Escola de Belas Artes da UFMG, discute experimentações realizadas com 0 beatbox em várias instâncias de produção, buscando verificar como cada um desses modos de criação potencializa aspectos distintos do Beatbox. Os experimentos descritos colocam em discussão a mistura de materialidades na criação musical, no seu uso como material didático, na criação de trilhas para espetáculos teatrais. Percebe-se uma busca interessante na confluência entre interfaces e o modo como cada uma delas cria e se relaciona com a noção de sons.

Como organizador do dossiê, agradeço a todos os colegas que cederam parte do seu tempo para produzir os textos, para discutir as abordagens possíveis, no sentido de construirmos um conjunto coerente de artigos na área de poéticas computacionais, ainda que diversificado. Após ter lido todos os textos, sinto que os mesmos terminam por estabelecer diálogos variados entre si, propondo ao leitor outras formas de contato entre os conceitos abordados. Penso ser essa a potência das poéticas computacionais: ao serem programáveis, se estabelecem enquanto proposições para uma discussão coletiva, conquanto também sejam capazes de gerar criações artísticas específicas, que não se deixam serem analisadas a partir de um ponto de vista que as encerre em alguma estrutura lógica fechada.

Texto recebido em junho de 2013.

Texto Digital, Florianópolis, v. 9, n. 1, p. 169-171, jan./jul. 2013. ISSNe: 1807-9288 